\title{
Islamic Content on Malaysian TV: A Case Study of TV Al Hijrah
}

\author{
${ }^{1}$ JULIANA ABDUL WAHAB, ${ }^{2}$ ZATIL HIDAYAH ABDULLAH \\ 1,2, School of Communication, Universiti Sains Malaysia, Penang, Malaysia \\ email: ${ }^{1}$ julia@usm.my ; ${ }^{2}$ zatil.1109@gmail.com
}

\begin{abstract}
Religion and media are converging and frequently becoming a subject matter for news content and popular entertainment programmes in television and film, publishing, music as well as the new media. Religion, arguably has become part and parcel of the media environment today. In Malaysian context, during the millennium era, many locally produced 'Islamic programmes' started to gain popularity among Malaysian audience especially within the entertainment genre such as television drama. With the establishment of Malaysian first Islamic free-to-air television, TV Al Hijrah in 2010, this paper aims to understand the nature of Islamic content available on the station. The preliminary findings of this paper suggest that there are varieties of television programmes created and aired on TV Al Hijrah cutting across different genres meant for disseminating Islam as a way of life. Programmes available are mainly about showcasing the values of Islamic teaching and beliefs with the ultimate goal to highlight Islam as a beautiful and peaceful religion.
\end{abstract}

Keywords: Islamic tv content, TV Al Hijrah, fiqh broadcasting

\section{Introduction}

In contemporary setting, religion and issues concerning religion have become one of the most important topics that have resurfaced and gain prominence in the media around the globe. Since the September 11 tragedy, more coverage about religion were produced and circulated on various media platforms. Hoover (2008) observes that the interaction between media and religion is becoming more apparent as both media and religion have endured significant changes in the recent years. Hoover (2008) further argues, religion and media are converging and frequently becoming a subject matter for news content and popular entertainment programmes in television and film, publishing, music as well as the new media. Religion has arguably become part and parcel of the media environment today.

In the media industry, there have been many changes in the development of technology which have resulted in the opening of different platforms that are able to disseminate media content and messages for the masses. The presence and discussion about religion on the media have become a common practice and are increasingly popular. In fact Hoover (2008) points out that there are more demands for religion materials on the media in the recent years partly due to the changes in the perspectives about the importance of religion-related issues among the masses.

Islamophobia has been an issue ever since the September 11, 2001 attacks up until now. It has become increasingly prevalent in the wake of ISIS attacks all over the world - the ideology and activities of ISIS have been equated to Islam, and Muslims in general are being portrayed in a very negative light in the media. In May 2015, Singapore Prime Minister Lee Hsien Loong highlighted that Southeast Asia had emerged as a "key recruitment center" for ISIS. Prime Minister Lee highlighted that, "The threat is no longer over there; it is over here" (Samuel, 2016).

At the regional level, Malaysia has taken up steps to participate in the ASEAN declarations in combating transnational crime and terrorism to ensure national and regional stabilities. The Malaysian government recognizes media as a powerful tool in disseminating ideas about religion, thus, in

Received: August 10, 2017, Revision: October 04, 2017, Accepted: December 18, 2017

Print ISSN: 0215-8175; Online ISSN: 2303-2499. DOI: http://dx.doi.org/10.29313/mimbar.v33i2.3193.447-454

Accredited B based on the decree No.040/P/2014, valid on February, 18, 2014 until February, 18, 2019. Indexed by DOAJ, Sinta, IPI 
2010 Malaysia's first free-to-air Islamic TV channel, TV Al Hijrah was established, partly as a response to the increasingly negative remarks about Islam. During the launch of the channel, the Malaysian Prime Minister was quoted saying,

\begin{abstract}
"We have to introduce the truth of Islam to the world, Islam has taken steps way ahead from anybody else in the effort of fighting for world peace and harmony. This is an important effort, as many opposing groups use our religion as a propaganda to critics Islam, to relate Islam to terrorism until they succeed to influence certain groups and creates Islamophobia." (Rosli, 2015: p.90).
\end{abstract}

\section{Methodology}

A content analysis was used to study a week of television scheduling from 10th16th July 2017. The content analysis was divided into two parts; the quantitative and qualitative. The quantitative part deals with analyzing the frequency and percentage of different genres and languages available on TV Al Hijrah in a week of television scheduling. Whereas the qualitative part of the analysis looked at the nature of content presented in various television genres. A descriptive qualitative analysis was done to top five programmes in different types of genres in order to further understand the approach of these programmes in their respective categories.

\section{Islam in Malaysian Context}

Malaysia is multicultural and multireligious country with Islam being the official religion. The population in 2017 is estimated at 32 million and $60 \%$ of the population practices Islam, 20\% Buddhism, 9.2\% Christianity, 6.3\% Hindu, 1.3\% Confucianism and the remaining is accounted for other types of religions (Taufik, 2017).

The Malaysian 1957 Constitution of Independence has endorsed Islam as an official religion and Sultans are the head of religion in their respective states. Article 11 (1) of the Malaysian Federal Constitution grants all citizens the freedom to profess, practice and propagate their own faiths. However, the freedom of religion in this country is subject to article 11 (4) which "... control [s] and restrict [s] the propagation of any religious doctrine among persons professing the religion of Islam." (Sheridan \& Groves,1987). In the Malaysian context it is common to accept that all Malays are Muslims, but on the other hand it is not necessarily common to assume that all Chinese or Indians are Buddhists, Hindus or Christians. In this respect, they are free to choose and practice their own faiths (Mazni \& Rizalawati, 2011).

Islam gained its importance in the country's agenda when the fourth Prime Minister, Mahathir Mohamad, introduced the Policy of Islamic Values in response to the Islamic revival movement that had taken Malaysia by storm in the early 1980s. Islamic resurgence movements emerged as a global political wave in the 1970 s roused by the Iranian Revolution. The movement in many ways have inspired Muslims around the world to use radicalism as means of freedom of expression and victory (Liew Chin Tong, 2015).

Islamic influence becomes increasingly popular by the late 1970 s and since then, there has been a noticeable consciousness rising among the Malays (Ahmad, 2004). There was also growth in dakwah movements (Islamic Propagation) organizations that emphasize the importance of understanding Islam and the need to adhere to the true teachings of Islam. The Malaysian government perceived the growing popularity of da'wah movements in the country as a threat to the authority (Raymond,1990 cited in Ahmad, 2004 ). This has resulted in the state taking action by sponsoring and regulating religious activities in Malaysia such as requiring permits for gatherings, building places of worships and establishing private Islamic schools. In 1988 , the Ministry of Information announced that Islam will be given airtime over radio and television (Aini Maznina et al., 2013). Other religions however, are free to propagate their teachings through the non-mainstream media.

Mahathir government's foresaw that the introduction of Policy of Islamic Values would help to curb Islamic radicalism in Malaysia during the 80s. The emphasize was on the mental and spiritual reform of society, in particular of the Muslim community in Malaysia (Mauzy \& Milne,1983; Mohammad Redzuan \& Amin Fadlillah, 2012). The implementation of the Policy of Islamic Values has fundamentally changed the economic, political, education, work culture and Malaysian administrative landscape.

In the increasingly strong sentiment of the Islamic movements among the Malay Muslims in Malaysia and the 9/11 attack, Islam once again underwent yet another 
renewal and rebranding by the fifth Prime Minister, Abdullah Ahmad Badawi when he introduced Islam Hadari or civilizational Islam, as a political and ideological campaign in 2004. The introduction meant to revitalize the essence of Islam in Malaysia. Islam was to be the basis for the country's development and aimed to further nurture knowledgeable, moral and virtuous society (Johan, 2010). After the victory of Barisan National (The National Front Party), Abdullah, proceeded to implement Islam Hadari as a means to promote the idea of progressive Islam based on the Islam Hadari 10 Principles. In response to the spirit of Islam Hadari, television stations in Malaysia had also started to adopt more "Islamic content" on Malaysian TV and more programmes were produced and aired during Abdullah's term as the Prime Minister.

\section{Malaysian TV Industry and The Rise of Islamic Content}

TV was first introduced in Malaysia in 1963. To date there are 8 free-to-air stations and 2 subscription-based TV. Offerings on radio and television are impinged upon by multi-ethnic makeup of the society and diverse religious practices in the country. Radio and television have to cater to the needs and demands of the society in a nonconflicting way among the diverse racial and religious groups. To facilitate that, the Ministry of Information provides guidelines to the state-owned radio and television stations requiring them to promote policies and programmes of the government; foster culture and civic consciousness and determine the type of entertainment being offered. In short, all broadcasting activities must promote government policies and fulfill aspirations of the government. This is expected of both informational and entertainment programmes.

In the early days leading up to the early 1980s, television industry in Malaysia, relied heavily on imported programmes mainly from Hollywood to fill in the air time slots. This was mainly due to lack of expertise and tight funding in the local industry to produce its own programming. Some of the in-house productions with low budget requirements were produced, however these programmes were poor in quality and could not meet the demand to fill in the airtime slots. In terms of programme content, majority were mainly focusing on disseminating government policies with few slots dedicated to entertainment programmes.

In 1983, the Malaysian government introduced the Privatization Policy, which resulted in more television stations being established in Malaysia. The year 1984 onwards can be regarded as the commercialization era in the television industry in Malaysia, due to the fact that more commercial television stations were established during this period. Prior to 1984 , only one government station with two free-to-air channels were allowed to operate in Malaysia. During the commercialization era, more programmes were imported and at the same time local productions gradually made appearances in the air time slots. With the launch of satellite television in 1996, the Malaysian television industry became more intense and more subscription based imported programmes were made available. Meanwhile, local programmes also started to gain popularity in the local scene and eventually gave rise to the copycat trend in Malaysia in the form of licensed or unlicensed adapted programmes.

The Millennium era from 2000 onwards sees imported programmes are still very prevalent in occupying the air time slots. Interestingly the imported programmes are no longer dependent on Hollywood productions but a mix of imported programmes originating from South East Asian region, typically from Indonesia, Thailand and the Philippines. These programmes play a major part in providing entertainment in Malaysian television industry. This aspect has in many ways popularized Indonesian Sinetron, K- Pop trend in Malaysia and reality TV.

As far as 'Islamic programme' is concerned, it was at the beginning of the millennium era that many locally produced 'Islamic programmes' started to gain popularity among Malaysian audience especially within the entertainment genre such as television drama. Prior to this, majority of 'Islamic programmes' produced were predominantly talked shows or 'preaching' oriented programmes mainly concerned with dakwah. The airing of Nur Kasih, a serial drama on TV 3 in 2009, can be regarded as a turning point in the Malaysian TV industry when it achieved phenomenal success around 19 million viewers per episode (Juliana, Wang Lay Kim \& Sharifah Shahnaz, 2013). From 2010 onwards more "Islamic content" in drama and reality TV were produced and become popular among Malaysian audience.

A study by Mazni \& Rizalawati (2011) revealed that out of the seven channels, only two free-to-air channels (NTV7 and 8TV) did not have any Islamic content (see table $1 \&$ table 2). This is due to the fact that 8 TV targets Chinese audience whereas NTV7 caters to urban English speaking audience. Interestingly their study also showed that only $13.5 \%$ of the total programming of 
the seven free-to-air Malaysian television channels consisted of Islamic programmes with Al Hijrah being the biggest contributor and TV9 as the second highest contributor of the Islamic programmes.

Table 1

\section{Islamic Content in All Channels}

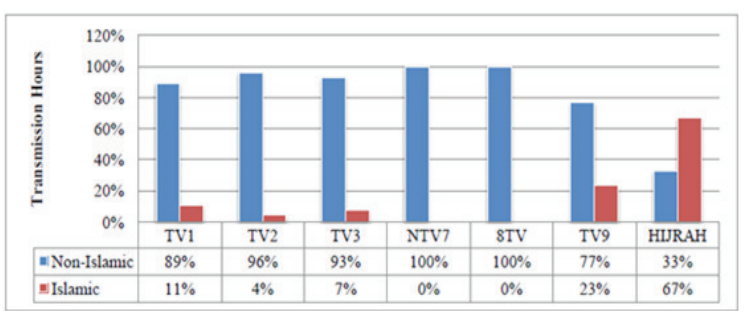

Source: Mazni \& Rizalawati, 2012:p.19.

Table 2

Total of Transmission Hours

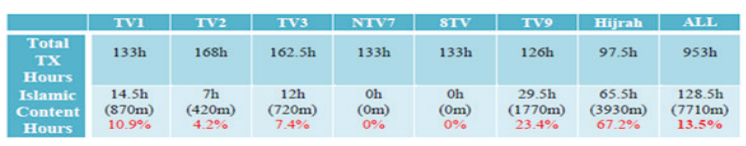

Source: Mazni \& Rizalawati, 2012:p.19.

Whilst there is a widespread of Islamic TV programming in the local television industry, interestingly, there are no specific policies regarding Islamic programs in Malaysia apart from a general guideline formed by the Department of Islamic Affairs Malaysia (JAKIM) for entertainment in Islam (Aini Maznina et al., 2013) which is based on the core principles of aqidah, sharia and akhlaq; and in line with the Islamic teachings and beliefs. Mainly these types of programme are meant to strengthen the Islamic belief and spread the Islamic thinking.

\section{TV Al Hijrah}

The emergence of TV Al-Hijrah is in fact an effort by the government of a Muslimmajority country to change the world's perception of Islam. TV Al-Hijrah is a stateowned, free-to-air television company under the Al-Hijrah Media Corporated, a company owned by the Malaysian Department of Islamic Affairs (JAKIM). The aim of its establishment is to become a medium that will educate, entertain and unite the Malaysian society; targeting at both Muslim and non-Muslim viewers (Zulkiplie, 2014). In short, TV Al Hijrah can be seen as one of the platforms to eliminate negative perception towards Islam by introducing Islam as the right and beautiful way of life.

TV Al Hijrah came up with its transmission plan on 1 July, 2010 from its headquarters in the Islamic Centre in Kuala Lumpur. TV Al
Hijrah was not the first Islamic television channel in Malaysia then as Astro Oasis, a paid channel; had already started broadcasting few years before. However, it is the first free-toair Islamic television channel in the country. With the introduction of TV Al Hijrah, a bigger portion of the Muslim population in Malaysia are able to access and enjoy more Islamicbased contents than before.

In 2016, Izelan Basar was appointed the Chief Executive Officer and he introduced a number of improvements to the programming of the channel. Among the new improvements introduced were the setting up of Al Hijrah Big Studios (ABS) in Cyberjaya, strengthening the Al Hijrah Media portal, setting up a radio station and introducing 30 new religious programmes with three signature shows. In addition, TV Al Hijrah would also launch four new channels - Muslim Lifestyle, Hijrah Kids (educating kids about Islam and its tenets), Hijrah Docu (research-based) and Hijrah Ilmu (religious sermons, Al-Quran and hadith). (www.star2.com, 2016).

When the station was first set up, TV Al Hijrah had a target of $60 \%$ offerings of local contents, $30 \%$ in house productions and the remaining $10 \%$ imported programmes. It has been reported that the viewership of TV Al Hijrah has grown significantly at a rate of $30 \%$ a year (Rosli, 2015). In terms of viewership a large portion of audience are housewives and in this respect Izelan stated that "... $70 \%$ of our viewers are housewives and women. So the whole outlook and the feel of the programme have to change. We have included new segments like the interaction and communication slot, which will be handled by the host, the popular Ustaz Don Daniyal Don Biyajid."(Zieman, 2016). Since September 2016, there has been an increase in the viewership of the channel and the subscription to its online portal alhijrahmedia.com has soared to almost half a million (ibid).

It is obvious that the presence of religious elements in the media in the current context has transcended beyond the spiritual aspects of the individual to include politics, lifestyle and entertainment. In the case of television, Osama \& Zulkiple (2015) argue that television is loaded with values that are made available for the masses. They also believes that high-valued television content disseminates valuable messages spreading all kinds of welfare to humankind whereas junk messages are worthless and serve only to promote unethical values. In order to advance valuable messages, the content of Islamic television has to have some kind of criteria that fit the spread of good teachings of Islam.

In this respect, fiqh broadcasting (Zulkiplie: 2014) can be used to understand 
the approach of disseminating Islamic values and teaching through television. According to Zulkiplie (2014) figh is a rule and judgment based on the evidences found in the shariah; that is according to Quran and Sunnah as well as consensus of Islamic scholar. He argues that "fiqh however does not override Shariah and is used to create laws for matters not specifically addressed by the Shariah." (ibid: p.287). To further understand the fiqh concept he further outlined three aspects that differentiate figh and shariah according to some Islamic scholars; firstly, shariah cannot be changed but figh can change based on new information, secondly, shariah is broad and general whereas figh focuses on narrow

Table 3

Shows and Number of Airtime by Genre (10 $10^{\text {th }}-16^{\text {th }}$ July 2017)

\begin{tabular}{|c|c|c|}
\hline Genre & Description/Comments & $\begin{array}{c}\text { Name of show and (number of } \\
\text { times aired in the week) }\end{array}$ \\
\hline $\begin{array}{l}\text { Talk Show } \\
\text { Total: } 54\end{array}$ & $\begin{array}{l}\text { Focusing on daily and current issues } \\
\text { such as daily lives, business, family } \\
\text { lives, as well as product promotions } \\
\text { - all discussed from the Islamic } \\
\text { perspective/with some Islamic elements } \\
\text { thrown in. }\end{array}$ & $\begin{array}{l}\text { Assalamualaikum (7), Assalamualaikum } \\
\text { 9am (7), Al Cuit Sikit (1), Betul Ke } \\
\text { Ustaz (7), B Frenz (14), Masam Masam } \\
\text { Manis (1), Sejuta Rahsia (2), Kembali } \\
\text { Fitrah (2), Ilm Fest (1), Into Taqwa Mizz } \\
\text { Nina ENG (1), Che Din Kan Ada (1), Saf } \\
\text { Muslimah (10) }\end{array}$ \\
\hline $\begin{array}{l}\text { Preachings } \\
\text { Total: } 12\end{array}$ & $\begin{array}{l}\text { Straight out preachings, discussions } \\
\text { on hadiths, aqidah as well as other } \\
\text { religious matters. }\end{array}$ & $\begin{array}{l}\text { Cinta IImu Fiqh Syariah (2 ), } 30 \text { Minit } \\
\text { Ustaz Don Daniyal (3), Cinta Ilmu } \\
\text { Akidah \& Falsafah (2), Taman Syurga } \\
\text { Habib Ali (2), Mimbar (1), Cinta Ilmu } \\
\text { Celik Hadis (1), Cinta Ilmu Medan Fatwa } \\
\text { (1) }\end{array}$ \\
\hline $\begin{array}{l}\text { Drama/Series } \\
\text { Total: } 13\end{array}$ & Islamic-based narrative & $\begin{array}{l}\text { Salju Sakinah (2), Walau Sedetik Cuma } \\
\text { (2), Maahad Al Amin SS1 (2), Selamat } \\
\text { Malam Kekasih (3), Doa Untuk Aku (3), } \\
\text { Payung Emas (1) }\end{array}$ \\
\hline $\begin{array}{l}\text { Children (Zon } \\
\text { Aulad) } \\
\text { Total: } 20\end{array}$ & $\begin{array}{l}\text { 'Zon Aulad' generally refers to children's } \\
\text { programmes on TVAH. The title 'zon } \\
\text { aulad' in the next column does not refer } \\
\text { clearly to any specific programme. It } \\
\text { can be animated series, baby khalifah, } \\
\text { kids news or chef kecil. }\end{array}$ & $\begin{array}{l}\text { Kids News (6), Chef Kecil (2), Zon Aulad } \\
\text { (1), Baby Khalifah (4), Aiman Kembara } \\
\text { (2), Misi Ady (3), Impian Remi (1), } \\
\text { Ahmad Muhammad (1) }\end{array}$ \\
\hline $\begin{array}{l}\text { Travel } \\
\text { Total: } 5\end{array}$ & $\begin{array}{l}\text { Travelogues; involving the "halal" way } \\
\text { of traveling (strict observation of food } \\
\text { and prayers) as well as meeting Muslim } \\
\text { communities living abroad }\end{array}$ & $\begin{array}{l}\text { Dengan Basikal Aku Menjelajah (2), } \\
\text { Tetamu Masjid (1), Kembara Asyraf (1), } \\
\text { Kembara Ilmu (1) }\end{array}$ \\
\hline $\begin{array}{l}\text { Documentary } \\
\text { Total: } 4\end{array}$ & $\begin{array}{l}\text { In this given week; the themes were } \\
\text { history and architecture. }\end{array}$ & $\begin{array}{l}\text { The Truth (1), Ayat Riwayat (1), Per } \\
\text { Square Feet (2) }\end{array}$ \\
\hline $\begin{array}{l}\text { Home \& Living } \\
\text { Total: } 14\end{array}$ & Cooking shows and product promotions. & $\begin{array}{l}\text { Menu Alam (4), Chef Ammar (3), Home } \\
\text { Shopping (7) }\end{array}$ \\
\hline $\begin{array}{l}\text { Education } \\
\text { Total: } 6\end{array}$ & $\begin{array}{l}\text { Educating the viewers on techniques of } \\
\text { reading and learning the Quran. }\end{array}$ & $\begin{array}{l}\text { Al Furqan (1), Madrasah Al Hijrah (4), } \\
\text { Al Maraya (1) }\end{array}$ \\
\hline $\begin{array}{l}\text { Adhan, Zikir \& } \\
\text { Salawat } \\
\text { Total: } 49\end{array}$ & $\begin{array}{l}\text { Praise and remembering Allah \& } \\
\text { Prophet Muhammad }\end{array}$ & $\begin{array}{l}\text { Saat Syahdu (7), Dhuha (7), Panggilan } \\
\text { Agung (35) }\end{array}$ \\
\hline $\begin{array}{l}\text { Music } \\
\text { Total: } 13\end{array}$ & Nasheed songs. & Melodi Iman (13) \\
\hline $\begin{array}{l}\text { Current Issues } \\
\text { Total: } 7\end{array}$ & Islamic-based. & Malam D Hijrah (7) \\
\hline $\begin{array}{l}\text { News } \\
\text { Total: } 14\end{array}$ & $\begin{array}{l}\text { Current issues, both national and } \\
\text { international. }\end{array}$ & Berita Arab (7), Berita Alhijrah (7) \\
\hline $\begin{array}{l}\text { Reality Show } \\
\text { Total: } 5\end{array}$ & Islamic-based. & $\begin{array}{l}\text { Langit Terang (1); Queen of the Deen } \\
\text { (1); Ejen Halal (1); Finding Him (vlog } \\
\text { series) (1); U Turn (1) }\end{array}$ \\
\hline
\end{tabular}


and specific issues and thirdly shariah comes from Quran and Sunnah but figh broadcasting comes from shariah (ibid).

In the case of TV Al Hijrah, the station adopts the concept of Islam as a way of life. Additionally, with regards to shariah and fiqh broadcasting, TV Al Hijrah establishes several guidelines to ensure that all the programmes aired on TV Al Hijrah stay in line with Islamic principles. In general, all contents that are degrading to the religion, creating disunity among Muslims and causing destructive and harmful effects to society are totally prohibited and all contents with elements that deviate from Islamic teachings and practices are also prohibited (Zulkiplie, 2014:p.289).

Table 4

Frequency and Percentage According to Genre (10th -16th July 2017)

\begin{tabular}{|l|c|c|}
\hline \multicolumn{1}{|c|}{ Genre } & $\begin{array}{c}\text { Frequency } \\
\text { per week }\end{array}$ & \% \\
\hline Talk show & 54 & 25 \\
\hline $\begin{array}{l}\text { Adhan, Zikir \& } \\
\text { Salawat }\end{array}$ & 49 & 6 \\
\hline Children & 20 & 6 \\
\hline Home\& Living & 14 & 9 \\
\hline News & 14 & 2 \\
\hline Drama/Series & 13 & 2 \\
\hline Music & 13 & 6 \\
\hline Preachings & 12 & 3 \\
\hline Current Issues & 7 & 23 \\
\hline Education & 6 & 6 \\
\hline Travel & 5 & 3 \\
\hline Reality Show & 5 & 7 \\
\hline Documentary & 4 & 2 \\
\hline Total & 216 & 100 \\
\hline
\end{tabular}

Table 5

Percentage of TV shows by genre (10th -16th July 2017)

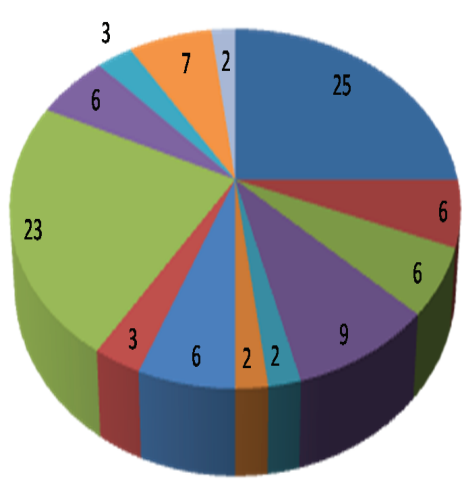

Talk Show

IPreachings

n Drama/Series

IChildren

-Travel

nocumentary

- Home \& living

IEducation

هAdhan, Dhikir \& Salawat

Inusic

\section{Discussion}

The analysis showed that a variety of genres were made available on television Al Hijrah ranging from factual to entertainment programmes. Factual programmes include adhan, zikir \& salawat, talk shows and news to name a few. On the other hand, programmes such as drama, music and cooking shows can be regarded as entertainment programmes. In the analysis, it was also evident that majority of the programming consisted of talk shows (25\%) which were aired 54 times throughout the week (about seven times per day). The second biggest genre in TV Al Hijrah is adhan, zikir and salawats $(23 \%)$ which were aired 49 times per week. Children programmes on the other hand was the third largest $(20 \%)$ type of programme aired on TV Al Hijrah at a frequency of 20 programmes a week. The least frequent genre shown on TV Al Hijrah was documentary (2\%) at a frequency of only 4 shows throughout the week.

\section{Adhan, Zikir \& Salawat}

This genre had the highest frequency compared to the other genres on TV Al Hijrah. The audience was summoned to remember and praise the greatness of Allah, which was meant to strengthen the spiritual aspect.

\section{Talk Show}

Majority of the talk shows focused on daily and current issues such as daily life, business, family, as well as product promotions - all discussed from the Islamic perspective/with some Islamic elements thrown in. For example, business-related shows such as B Frenz and Saf Muslimah, as well as the promotional segment Souq@ Assalamualaikum were promoting products owned by Muslim entrepreneurs or brands. Most of these brands are new in the market, hence TV Al Hijrah in this case served as a platform for them (Muslim entrepreneurs/ brands) to start promoting their products. In addition, the business segments in Assalamualaikum and the show Che Din Kan Ada highlighted business and financial issues from the Islamic perspective (e.g. Saham Waqaf Larkin Sentral).

Another interesting issue highlighted by this genre was about converts (muallafs). Shows such as Assalamualaikum and Kembali Fitrah featured new converts such as Raffiqin Low, Aliza Kim and Felixia Yeap. The guests discussed their 'journey' towards embracing Islam and their experiences after converting, with the audience. Talk shows such as Al Cuit Sikit and Masam-Masam Manis focused on the theme of relationships and family life. However there was a difference between the 
two: Al Cuit Sikit adopted a more laid-back vibe with a little bit of Islamic elements. Masam-Masam Manis, however, was the opposite - the discussions which related to relationships and family life concentrated more on the Islamic perspective and not as laid-back as Al Cuit Sikit.

\section{Children/Zon Aulad}

Zon Aulad generally refers to children's programmes. The term "aulad" means child in Arabic. The content of this segment consisted of a variety of shows. The language of the shows were either Malay or English. Contents that were purely Islamic in nature included Baby Khalifah, which was an educational show for young children. In this show, Islamic contents such as the basics of prayers and akhlaq were included. Besides that, the show also doubled as a medium for Malaysian children to learn English. Some contents, such as the animation series Misi Ady and the cooking show Chef Kecil did not fall exactly into the 'Islamic' category; they were rather neutral.

\section{Drama Series}

This genre mostly consisted of Islamicbased content; they were series depicting daily life with some Islamic elements (e.g., location, dressing, themes) added. Salju Sakinah: A series about a woman named Sumayyah and her journey of overcoming the struggles in her life - her father passed away while she was studying abroad and she had to take up his position in his business, her love life (torn between past and present lovers), her brother (and wife)'s involvement in Tok Mit's cult and her failure in one of her subjects in Jordan (she had to return to Jordan for that). Overall, the drama portrayed Sumayyah as a strong Muslim woman who could overcome any challenge in her life.

Maahad Al Amin SS1 was a comedy series revolving around a religious school, Maahad Al-Amin and its caretaker, Hud. Hud was a caretaker of the school but at the same time he was very talented in science, mathematics and invention - he loved to invent new things. Hud was also hardworking, alongside his best friends. Together they sought for side jobs in order to fund the school's operations - which is contrary to the stereotypical religious school in Malaysia that are said to be dependent on donations. This series was an attempt to portray religious schools in a different and more positive light. Payung Emas was yet another comedy centered around the controversial theme of polygamy. At first glance it seemed to portray the theme (and the male protagonist's habit of seeking new wives) in a cynical way. However, the ending being the first and second wife having to agree with his third marriage showed otherwise - that this show was in support of polygamy.

\section{Home and Living}

This genre consisted of cooking shows such as Menu Alam and Chef Ammar and living shows such as Home Shopping. Menu Alam was a location and ingredient-based cooking show. This was a rather different concept as each episode would feature a certain location and ingredient. In the show, the chef explained in detail about the ingredient, its habitat and nutritional values in addition to cooking demonstrations. Chef Ammar was a cooking show that featured Chef Ammar Al-Ali, a Middle-Eastern chef who could speak English, Malay and Arabic in addition to his cooking skills. Most of the recipes featured were of the Mediterranean/ Middle-Eastern origin.

It is apparent from the preliminary analysis that zikir, adhan and salawat, and preaching programmes available on TV Al Hijrah were concerned with the effort to strengthen the spiritual aspects of the lives of Muslims. Audience was summoned to remember and praised the greatness of Allah. Similarly in the entertainment genre such as music, songs were used as a medium of remembrance of Allah and His messenger, Prophet Muhammad. Whereas the talk show programmes aired on TV Al Hijrah talked about various issues of current affairs from an Islamic perspective involving experts and professionals representing their respective fields or professions. Meanwhile television dramas on TV Al Hijrah took an Islamic approach in the production style in which, the narrative, aspects of cinematography or even acting style were done based on Islamic principles meant for disseminating good moral conduct elements in the storylines. For other television programmes, in general, it was observed that TV Al Hijrah strived to develop a more meaningful content based on Islamic teachings and beliefs.

\section{Table 6}

Percentage of programmes by language $\left(10^{\text {th }}-16^{\text {th }}\right.$ July 2017$)$

\begin{tabular}{|l|c|c|}
\hline \multicolumn{1}{|c|}{ Language } & Frequency & Percentage \\
\hline Malay & 151 & $70 \%$ \\
\hline English & 9 & $4 \%$ \\
\hline $\begin{array}{l}\text { Arabic (Adhan, zikir, } \\
\text { salawat) }\end{array}$ & 56 & $26 \%$ \\
\hline Total & 216 & $100 \%$ \\
\hline
\end{tabular}

From the analysis, it is also evident that majority of the programmes aired were in the Malay language at $70 \%$ of the total output 
in a week. Arabic language came in second, to include programmes such as zikir, adhan and salawat. English programmes contributed a very small percentage, overall. This also indicates that over $70 \%$ of the content in TV Al Hijrah for this given week were locally produced.

\section{Conclusions}

It is evident that for the case of Malaysia, the millennium era has opened up many doors for television industry to flourish. The establishments of Astro Oasis, a pay TV and TV Al Hijrah, Malaysian first free-to-air TV have shown a positive development of Islamic television content in local setting. The spread of Islamic propagation has been given a new approach to touch the heart of the masses. Television is identified as one of the important platforms to disseminate the teaching of Islam typically among the Muslim community in this country. Many programmes that were made available on TV Al Hijrah in various kinds of genre, for the purpose of generating interest among audience from different age groups and backgrounds such as children, adults, housewives and the non-Muslim community to name a few. Most of the programmes aired on TV Al Hijrah were anchored in the spirit of fiqh broadcasting that is meant to strengthen the Islamic belief, spread the Islamic thinking and reinforce Islamic culture and above all highlighting Islam as a way of life.

\section{References}

Ahmad, F.Y. (2004). An Islamic responses to non Muslim concerns. Paper Presented at International Association for the History of Religions. Yogyakarta, Indonesia. 27 October.

Aini Maznina, A. M. et al. (2013). The acceptance of TV Islamic reality shows by the Malay community. 'Ulum Islamiyyah Journal. The Malaysian Journal of Islamic Sciences. 10 (June), 93-116.

Hoover, M.S. (2008). Media and religion. The center for Media, Religion and Culture: University of Calorado, USA.

Juliana, A.W., Wang, L.K. \& Sharifah Shahnaz, B. (2013). Asian dramas and popular trends In Malaysian television industry. Available from: http://www.ukm.my/jkom/ journal/pdf_files/2013/V29_2_159-174.pdf [Accessed 10 th November 2017].
Johan, S.(2010). Encounters of Muslims in Malaysia. In: Johan,S.(eds). Islam and politics in South East Asia, USA: Routledge. pp.85-105.

Liew, C.T. (2015). The evolution of political Islam in Malaysia. Available From: https:// www. malaysiakini.com/news/313604 [Accessed 17th October 2017].

Mauzy, D.K. \& Milne, R.S. (1983). The Mahathir administration in Malaysia: Discipline through Islam. Pacific Affairs. 56 (4), 617-648.

Mazni, B. \& Rizalawati, I. (2011). Islamic programs in Malaysian free-to-air television channels. Paper presented at the International Conference on Islamic Civilization and Malay Identity. Malacca, Malaysia. $1^{\text {st }}$ October.

Mohammad Redzuan, O. \& Amin, F. (2012). Perspektif badan bukan kerajaan ( $\mathrm{Ngo}$ ) Islam terhadap dasar penerapan nilai-nilai Islam dan pendekatan Islam Hadhari. Available from: http://journalarticle. ukm.my/5330/1/makalah-v4n1-n3.pdf [Accessed 10th November 2017].

Osama K. \& Zulkiple, A.G. (2015). Islamic television programs: Content and format revisited. 'Ulum Islamiyyah Journal. The Malaysian Journal of Islamic Sciences. (16) December, 169-185.

Rosli M. (2015). The impact of character branding through media: A case study of TV Al-Hijrah's Ustaz celebrity programme. Journal of Islamic Research. 9 (2), 88-105.

Samuel, T.K. (2016). Radicalisation in Southeast Asia: A selected case study of Daesh in Indonesia, Malaysia and the Philippines (Monograph). The Southeast Asia Regional Centre for Counter-Terrorism (SEARCCT), Kuala Lumpur.

Sheridan, L.A. Groves, H.E. (1987). The Constitution of Malaysia. Malayan Law Journal Singapore.

Taufik, Y.Y.H. (2017). Islam agama untuk manusia segajat. Harian Metro, 26 January 2017.

Zieman, (2016). TV AlHijrah shifts focus under the direction of new CEO.Available from: http://www.star2.com/entertainment/ tv/2016/09/11/tv-alhijrah-shifts-focusunder-the-direction-of-new-ceo/ [Accessed 12 November 2017].

Zulkiple, A.G., (2014). Fiqh broadcasting: A comparative study of television program production in Malaysia and Iran. Advances. in Natural Applied. Science. 8(4) , 286-290. 